\title{
Lessons in Leading: Developing a Culture of Innovation in Public Sector Planning and Governance
}

\author{
William Riggs \\ PhD; Assistant Professor, CRP Cal Poly.
}

In this thought provoking article, William Riggs discusses the importance and principles of leadership, and how they can help efficiency, community satisfaction, and innovation in public planning and governance. Leadership in the public sector is more about creating an environment for success and unleashing the power of others.

$\mathrm{M}$

ost of us would agree that effective leadership is vital to any organizational efficiency in business. Great leaders communicate the mission and objectives of an organization, inspire motivation, and lead teamwork to more efficient and productive outcomes (Northhouse, 2014). But what about in the public sector; does visionary leadership matter? Academics would tell us that effective leadership is obviously not only a priority for the private sector and that leadership in the public sector is a critical part of developing a culture of innovation in government (Ingraham \& Getha-Taylor, 2004; Ingraham, Joyce, \& Donahue, 2003; Newman, Raine, \& Skelcher, 2001; Wright \& Pandey, 2010; Zien \& Buckler, 1997).

Since leadership plays a crucial role in two factors believed to drive employee satisfaction, utilizing employee skills and teamwork, developing and sustaining effective leaders for the government of the 21st century is fundamental (Ingraham \& Getha-Taylor, 2004). An analysis of management capacity and the "potential for performance" in federal agencies and state and local governments reported that in each case where strong management capacity was developed, strong leadership was also present (Ingraham, Joyce, \& Donahue, 2003). But, what traits make up a great public sector leader?

Scholars have researched many different models of what constitutes effective leadership. These include trait-based or personal characteristic theories (Northhouse, 2014), or relational ones that deal with the leaders and subordinates, or leadermember exchanges, and visionary organizational change and integrative approaches (Moynihan \& Ingraham, 2004). The field has focused on the role of the strategic leader, a leader "of" individuals (Bryman, 2013) focused on developing shared vision and meaning (Boal \& Schultz, 2007), and developed more of a shared leadership style that focuses on the idea of culture (Carson, Tesluk, \& Marrone, 2007; Manz, Pearce, Mott, Henson, \& Sims, 2013; Pearce \& Conger, 2002; Sarros, Cooper, \& Santora, 2008), and four principles of leadership including confidence, questioning, learning, and service (Lyons, 2012).
These factors can create a culture of innovation (Lyons, Chatman, \& Joyce, 2007) founded on guiding principles that can help reframe leadership. The guiding principles are what former Mayor of New York Rudy Giuliani would see as a defining rudder that can help managers cope with the workload demands and public scrutiny of their jobs. In his opinion, "having strong beliefs [principles], being able to stick with them through popular and unpopular times, is the most important characteristic of a great leader" (Giuliani \& Kurson, 2003).

Giuliani's example provides muster to the argument that the four principles of leadership apply in the public sector and are essential for public agency management. These principles have been discussed prominently by Lyons (2011) and include:

Confidence - Being confident in your skills without pretense or attitude;

Questioning - Questioning the norm, the status quo / the mainstream and standing up for what you know to be true;

Learning - Learning from anyone and to never stop learning;

Service - Serving something greater and thinking beyond yourself.

Using a series of case studies and interviews this article illustrates the opportunities and challenges of leading and managing in the public sector. This is framed by a central assumption - that leadership and management are not dichotomous-and that leadership is a critical trait for public sector managers. It also relies on the idea that the areas of confidence, questioning, learning, and service can be seen as hierarchical with service and learning underscoring the core of public sector planning. This is depicted in Figure 1 and used to frame discussion and application to government in each of these areas.

\section{Confidence - Confidence Without Pretense}

Of these factors that are path-bending with regard to organizational management, confidence without pretense provides a 


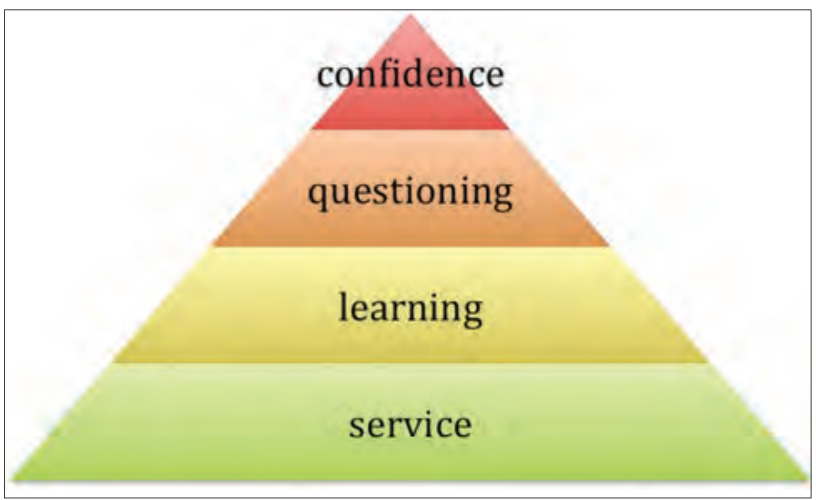

Figure 1: Hierarchy of public sector leadership traits.

first lesson. For example, in a recent discussion with students of CRP 530, Dr. Robert Bertini, Professor at Portland State University and Former Deputy Administrator for the U.S. Department of Transportation (USDOT), encouraged outright ambitiousness: "Big projects take a long time. I have very simple advice; be ambitious but patient."

Dr. Bertini became a member of the Obama administration in 2008 as the director of the Research and Innovative Technology Administration (RITA). He saw large projects come to fruition through the themes of coordination and coercion. According to him, in the United States congestion leads to 4.8 billion hours in travel delay for auto commutes and there is no easy solution for this especially in governance. Therefore, it takes confidence to re-envision the way things are organized and prioritized.

Dr. Bertini described his first day as one where he had to be both inventive and receptive-projecting a vision and new strategic plan for policy but also being open and receptive to the best ideas from anybody-from people who may have been with an organization for thirty minutes to those who had been there thirty years. This involves shedding one's ego at the door-having confidence without attitude.

\section{Questioning - Questioning the Norm}

In the same way questioning the norm is important. This is something that is reinforced as far and wide as Chief William (Bill) Bratton who revolutionized policing in New York City, and in California by City of San Luis Obispo Mayor, Jan Marx and City of Berkeley Planning Director, Eric Angstadt, both of whom have spent decades in planning and city government. Each of these individuals has taken a unique perspective on thinking about and responding to the status quo in their respective organizations.

In New York City, Bill Bratton gained notoriety in the late 1990 s by questioning the traditional methods of law

${ }^{1}$ Dr. Bertini will be joining Cal Poly' Department of Engineering in the fall of 2014. enforcement and using new ideas and technology to reduce crime (Sugarman, 2010). He replaced a number of senior staff members and implemented what he called a "COMPSTAT" meeting where leadership would strategize approaches to crime fighting (Willis, Mastrofski, \& Weisburd, 2004). At these meetings, different personnel of the New York Police Department (NYPD) were able to communicate to develop effective strategies-one of the most simple being changes in the police uniforms and equipment that made beat cops look more professional and official giving them pride in how they looked that translated internally and externally.

Likewise, in a 2013 discussion with CRP students Mayor Marx and Planning Director Angstadt talked about how great managers are leaders, and leaders set the agenda and lay out not only a policy vision but the political process to achieve it. In Mayor Marx's mind this concept is the key way to establish power in government, but she advises students to remember that while you are questioning the status quo and being dynamic, you need to stay in touch with what your community wants. According to Mayor Marx, "If you look in back of you and no one is following you then you are doing something wrong."

To stay focused she advises students to pay attention to details and respect everyone. Sometimes the public can say silly things that can make her want to laugh but she advises students not to laugh. Instead, students should take public comments to heart and see where there are things you can question and take action on. Complimenting this, Director Angstadt uses this data as a filter for looking at the municipal budget, which he saw as the keystone to questioning what works and does not work, and then meeting city goals.

\section{Learning - Never Stop Learning}

These examples of questioning and inquiry get at a larger foundational issue that deals with learning. True leaders never stop learning (Argyris, 1976; Copland \& Knapp, 2007; Sosik, Godshalk, \& Yammarino, 2004). As John F. Kennedy is quoted as saying, "Leadership and learning are indispensable to each other." A widely known example of this is Coach Mike Kryzewski, or Coach K, who has led the Duke University Basketball team to multiple NCAA championships during his career. Coach $\mathrm{K}$, has been able to accomplish much of this by his unique approach to leadership which is not to let "Too many rules get in the way of leadership..." which can "... put you in a box" and keep you from learning and making decisions (Snook, Perlow, Delancy, \& Coach, 2005). He is known for saying, "I don't want to be a manager or dictator. I want to be a leader-and leadership is ongoing, adjustable, flexible, and dynamic."

Likewise, City of San Luis Obispo planner, James David, has spoken with Cal Poly students about learning from the public as he engages them. James has the perspective that as a civic manager you can foster civic empowerment and be credible by being in front of your constituency as much as possible, and learning as much as possible, using creative tools to seek 
real feedback. One of his most significant memories was from working local transportation planning issues and learning from elementary school students about what the city could do to make riding the transit cooler. To this they gave him a surprising, and yet not so surprising, comment: "Put Fergie on the bus!"

\section{Service - Serving Something Greater}

Finally, as a capstone for public sector management, comes the idea of service and serving something greater. This is a topic of high import that both David Storms, who works as Division Director for the Office of Public Housing of the federal Department of Housing and Urban Development (HUD), and Daryll Grigsby, the Public Works Director for the City of San Luis Obispo, espouse. Both individuals spoke with CRP students in the spring of 2013 and encouraged those entering into (and in) the planning and policy fields to keep a service mindset and let this be the foundation of their careers. Storms explained that HUD's mission has changed in recent years: "We used to be housing 'cops' waiting to say 'gotcha'. Now I view our relationship as a partnership with our customers."

He uses this principle of partnership for service to motivate his federal employees. There are many stereotypes of government employees, but he thinks by-and-large most people go into government wanting to make the world a better place. He tries to tap into that, especially for employees who are older and may feel isolated or out of touch with younger leaders. "Remind them of their personal values and how they are related to institutional goals," he says. Remind them that they serve something greater.

Grigsby taps into a similar ethos. While his number one lesson to serve communities is to "have a handle on the budget" so that you can respond with tangible solutions and improvements, he is especially sensitive to dealing with public service employees. Having worked through numerous economic cycles of prosperity and scarcity in government his advice is to be stable.

"Don't take the lows too low, or the highs too high. Both will balance out. You will need to keep people's morale and focus when things are low. Even if there are no lay-offs or jobs lost, there is a vibe of scary. . . . Ultimately the workplace is like a family. You see them more. You are walking down life's path with them; babies, death, and the family. Everyone has the same desires: live life, have family, have balance."

He reminds us that two key lessons are remembering that none of us 'live to work' and that being a service-oriented public servant is not complex but simple, and instilled in most of us at a very early age:

"One trick to management is remembering the things that my grandmother taught me when I was a child: respecting people; communicating; listening; and treating human beings like the adults they are."

\section{Conclusions}

These lessons in leading provide both a guidebook and reminder for those entering public sector leadership positions. As this article indicates, leadership in the public sector is malleable and dynamic-more about creating an environment for success and unleashing the power of others than about being powerful in your own right. This is not magic or a special sauce, and may be more heartfelt and organic than we all imagine, but there are tangible things we can do to create a culture of innovation, one thing that some have described as the intangible passion and excitement for tasks and responsibilities.

Keying in on the ideas of confidence, questioning, learning, and service can be one way to move toward this and to begin creating path-bending environments where public sector employees can thrive. We can be leaders who, in the words of Emerson (2006):

"Do not go where the path may lead, go instead where there is no path and leave a trail."

\section{Path-Bending Ideas for Planning \& Governance}

Ideas you may or may not have thought of to reshape your organization.

- Serve coffee or start a snack bar. Think of simple gestures that can bring about informal interactions that foster culture.

- Create a big idea wall in the office to encourage innovation and risk taking.

- Express gratefulness. Write an email or a note of thanks. The message can be as simple as "Your performance was among the very best. I appreciate the effort." and can be a low cost, high impact way recognize your top performers.

- Make your website mobile friendly and stream public meetings online.

- Create a way for the public to be creative and outlets for employees to do hands-on service. This could include things like street art or helping install or maintain landscaping.

- Borrow from the airlines and use a kiosking and concierge model for over-the-counter planning that provides a human touch and reduces workload.

- Do away with 'the snake' and use an online 'BuzzFeed'-style quiz to improve understanding of the permitting process. Integrate this with an e-permitting system. 


\section{References}

Argyris, C. (1976). Leadership, learning, and changing the status quo. Organizational Dynamics, 4(3), 29-43.

Boal, K. B., \& Schultz, P. L. (2007). Storytelling, time, and evolution: The role of strategic leadership in complex adaptive systems. Leadership Quarterly, 18(4), 411-428.

Bryman, A. (2013). Leadership and organizations. London, England: Routledge. Retrieved from http://books.google. com/books?hl=en\&lr=\&id=FMxpG-vAspQC\&oi=fnd\&pg = PP1\&dq=Leadership+in+Organizations, +In\&ots=1 Juy0q b7sg\&sig=hyWBKWPupLxG9Y3cOgxjk-UcVsM

Carson, J. B., Tesluk, P. E., \& Marrone, J. A. (2007). Shared leadership in teams: An investigation of antecedent conditions and performance. Academy of Management Journal, 50(5), 1217-1234.

Copland, M., \& Knapp, M. (2006). Connecting leadership with learning: A framework for reflection, planning, and action. Alexandria, VA: Association for Supervision and Curriculum Development.

Emerson, R. W. (2006). Ralph Waldo Emerson: Selected essays, lectures, and poems [Reissue edition]. New York, NY: Random House. Retrieved from http://books.google. com/books?hl=en\&lr=\&id=jmijL21 KXLoC\&oi=fnd\&pg=P$\mathrm{A} 1 \& \mathrm{dq}=$ Emerson, + Essays+\%26+Lectures+\&ots=YNICyFA -cN\&sig=Z0yY-aJa78yCKak-iJsvkzn3G5Q

Giuliani, R. W., \& Kurson, K. (2003). Leadership. New York, NY: Time Warner Paperbacks.

Ingraham, P. W., \& Getha-Taylor, H. (2004). Leadership in the public sector: Models and assumptions for leadership development in the federal government. Review of Public Personnel Administration, 24(2), 95-112.

Ingraham, P. W., Joyce, P. G., \& Donahue, A. K. (2003). Government performance: Why management matters. Baltimore, MD: Johns Hopkins University Press. Retrieved from http://books.google.com/books?hl=en\&lr=\&id=6tdYJsFz fzIC\&oi=fnd\&pg=PP13\&dq=Ingraham,+Joyce+\%26+Don ohue, $+2003 \&$ ots $=$ gJd8JQMZGf\&sig=urruCdCENIw1 HMa 2ZJkGPmy1Cts

Lyons, R. (2011, January/February). Paths to innovative leadership. BizEd, 32-38. Retrieved from http://www.bizedmagazine.com/default.asp

Lyons, R. K. (2012). Curriculum reform: Getting more macro, and more micro. Journal of Management Development, 31(4), 412-423. Retrieved from http://www.emeraldinsight.com/journal/jmd

Lyons, R. K., Chatman, J. A., \& Joyce, C. K. (2007). Innovation in services: Corporate culture and investment banking. California Management Review, 50(1), 174-191. Retrieved from http://cmr.berkeley.edu
Manz, C. C., Pearce, C. L., Mott, J. W., Henson, Z., \& Sims, H. P., Jr. (2013). Don't take the lead...share the lead: Surprising leadership lessons from big time college sports. Organizational Dynamics, 42(1), 54-60.

Moynihan, D. P., \& Ingraham, P. W. (2004). Integrative leadership in the public sector: A model of performance-information use. Administration \& Society, 36(4), 427-453.

Newman, J., Raine, J., Skelcher, C. (2001). Developments: Transforming local government: Innovation and modernization. Public Money \& Management, 21(2), 61-68.

Northouse, P. G. (2014). Introduction to leadership: Concepts and practice [3rd ed.]. Thousand Oaks, CA: Sage.

Pearce, C. L., \& Conger, J. A. (2002). Shared leadership: Reframing the hows and whys of leadership. Thousand Oaks, CA: Sage.

Sarros, J. C., Cooper, B. K., \& Santora, J. C. (2008). Building a climate for innovation through transformational leadership and organizational culture. Journal of Leadership and Organizational Studies, 15(2), 145-158.

Snook, S., Perlow, L., \& Delancy, B. (2005). Coach, K: A matter of the heart. Harvard Business School (Case 406-044). Retrieved from https://brainmass.com/file/224689/ Coach+K-MatteroftheHeart.pdf

Sosik, J. J., Godshalk, V. M., \& Yammarino, F. J. (2004). Transformational leadership, learning goal orientation, and expectations for career success in mentor-protégé relationships: A multiple levels of analysis perspective. The Leadership Quarterly, 15(2), 241-261.

Sugarman, B. (2010). Organizational learning and reform at the New York City Police Department. The Journal of Applied Behavioral Science, 46(2), 157-185.

Willis, J. J., Mastrofski, S. D., \& Weisburd, D. (2004). COMPSTAT and bureaucracy: A case study of challenges and opportunities for change. Justice Quarterly, 21(3), 463-496.

Wright, B. E., \& Pandey, S. K. (2010). Transformational leadership in the public sector: does structure matter? Journal of Public Administration Research and Theory, 20(1), 75-89.

Zien, K. A., \& Buckler, S. A. (1997). From experience dreams to market: Crafting a culture of innovation. Journal of Product Innovation Management, 14(4), 274-287. 